\title{
Rode deletie
}

De verstomde herinnering aan het communisme van Anton de Kom

\author{
Karwan Fatah-Black
}

TVGESCH 130 (3): 467-483

DOI: 10.5117/TVGESCH2017.3.FATA

\begin{abstract}
Red erasure. The silenced memory of Anton de Kom's communism

In 1934 the Afro-Surinamese author and activist Anton de Kom published his Wij slaven van Suriname (We Slaves of Surinam). De Kom drew inspiration from his experience and life in Surinam, as well as from the writings of abolitionist authors and the communist and antiimperialist circles in which he moved while in Europe. Back in Surinam he was accused of plotting to overthrow the colonial government, and mass protests against his arrest were violently suppressed before he was deported to the Netherlands. During the Second World War he remained active in the anti-fascist resistance, and died in a German concentration camp. Remembering his struggle has become a cornerstone of Surinamese nationalism, important to anti-racist activists and important also to his children and grandchildren. This article discusses how these three sets of actors have often chosen to gloss over De Kom's communist allegiance.
\end{abstract}

Keywords: Anton de Kom, Suriname, communism, memory, erasure

In 1934 publiceerde Anton de Kom zijn Wij slaven van Suriname. ${ }^{1}$ Het was de eerste antikoloniale geschiedenis van Suriname

1 A. de Kom, Wij slaven van Suriname (Amsterdam 1934). Een inhoudelijk overeenkomstige inleiding over het leven en werk van Anton de Kom verscheen recentelijk in Karwan Fatah-Black, 'Genderrollen in het leven en werk van Anton de Kom', Historica 19.1 (2017) 3-7. De nadruk ligt in dit huidige artikel meer op de politieke oriëntatie, al vertonen de beschrijvingen van het boek en de schrijver noodzakelijkerwijs overeenkomsten. geschreven vanuit een Surinaams perspectief. Sinds de jaren zeventig zijn het boek en de auteur een hoeksteen geworden van het Surinaams nationalisme, antiracisme, en de antikoloniale kritiek in Nederland en Suriname. ${ }^{2}$ Vanaf het moment dat De Kom in 1926 begon met zijn schrijfproject

2 Peter Meel, 'Anton de Kom and the formative phase of Surinamese decolonization', New West Indian Guide / Nieuwe West-Indische Gids 83.1\&2 (2008) 249280 . 
tot de marketing, publicatie en latere Duitse vertaling, leverde de communistische beweging zowel organisatorische steun als ideologische inspiratie voor het boek.

Met de opkomst van de naoorlogse heldenstatus van De Kom verdwenen zijn communistische sympathieën echter uit beeld. Dit artikel biedt door middel van een herlezing van de tekst van Wij slaven een heroverweging van De Koms communistische sympathieën. ${ }^{3}$ Daarnaast geeft het een beeld van de verschillende manieren waarop de inspiratie die hij uit de Russische Revolutie en het communisme haalde de laatste decennia het slachtoffer is geworden van een welbewuste en specifieke vorm van stilzwijgen. ${ }^{4}$ De officiële Surinaamse herinnering aan De Kom, de opstelling van zijn erfgenamen en het gebruik van zijn intellectuele nalatenschap door antiracistische activisten lijken, ondanks de verschillen in de wijze waarop zij de erfenis van De Kom vormgeven, het stilzwijgen over zijn communistische sympathieën te delen. Het bewust onbesproken laten van dit aspect van De Koms denken, zouden we (analoog aan de fonologische term voor het inslikken van klanken) deletie kunnen noemen.

De communistische beweging is in het werk en volwassen leven van Anton de Kom alomtegenwoordig. De Kom werd geboren in Paramaribo op 22 februari 1898 en stierf in een Duits concentratiekamp op 24 april 1945. Hoewel hij werd geboren in een gezin afkomstig uit de

3 Hiervoor wordt de twaalfde druk gebruikt. Anton de Kom, Wij slaven van Suriname (Amsterdam 2009). 4 Een van de weinigen die de communistische inspiratie van Anton de Kom niet verzwijgt is Theo Para. Zie onder andere Theo Para, 'Anton de Kom en de menselijke waardigheid', OSO: Tijdschrift voor Surinamistiek en het Caraïbisch gebied 29.1 (2010) 103-111. middenklasse, leefde hij tijdens zijn jeugd in een relatief arm deel van Paramaribo. Velen onder de oudere generatie hadden de slavernij nog meegemaakt. Als jonge man werkte De Kom voor verschillende bedrijven in Suriname, waarna hij naar Nederland verhuisde om zijn geluk daar te beproeven. Gedurende zijn verblijf in Nederland werd zijn interesse voor radicale politiek gewekt en speelde hij een voorname rol in Nederlandse communistische en anti-imperialistische kringen. In 1933 besloot hij zich weer in Suriname te vestigen, met zijn Nederlandse vrouw Petronella Borsboom en hun vijf kinderen. ${ }^{5}$

De Kom keerde terug naar Suriname op het moment dat de arbeidersbeweging voor het eerst van zich liet horen en de koloniale overheid erg op haar hoede was voor communistische agitatie. Hoewel de georganiseerde communistische beweging klein bleef, hadden er in 1931 werklozenrellen in Paramaribo plaatsgevonden en waren vakbondsactivisten uit Curaçao en Brits-Guyana actief in het land. ${ }^{6}$ De koloniale autoriteiten waren zich bewust van de communistische activiteiten en De Koms reputatie als communist en agitator was hem vooruit gereisd. Een artikel van zijn hand werd in Suriname als pamflet verspreid. De Centrale Inlichtingendienst (CID) meldde al in 1932 aan het Ministerie van Koloniën:

Zijn [De Koms] redevoeringen zijn steeds zeer fel gericht tegen het kapitalisme en het imperialisme en tegen de bestaande

5 Frits van Suchtelen, 'Kom, Cornelis Gerhard Anton de,' in: Biografisch woordenboek van het Socialisme en de Arbeidersbeweging in Nederland, vol. 8 (2001) 105-109.

6 Ben Scholtens, Opkomende arbeidersbeweging in Suriname: Doedel, Liesdek, De Sanders, De Kom en de Werklozenonrust, 1931-1933 (Masusa 1986). 


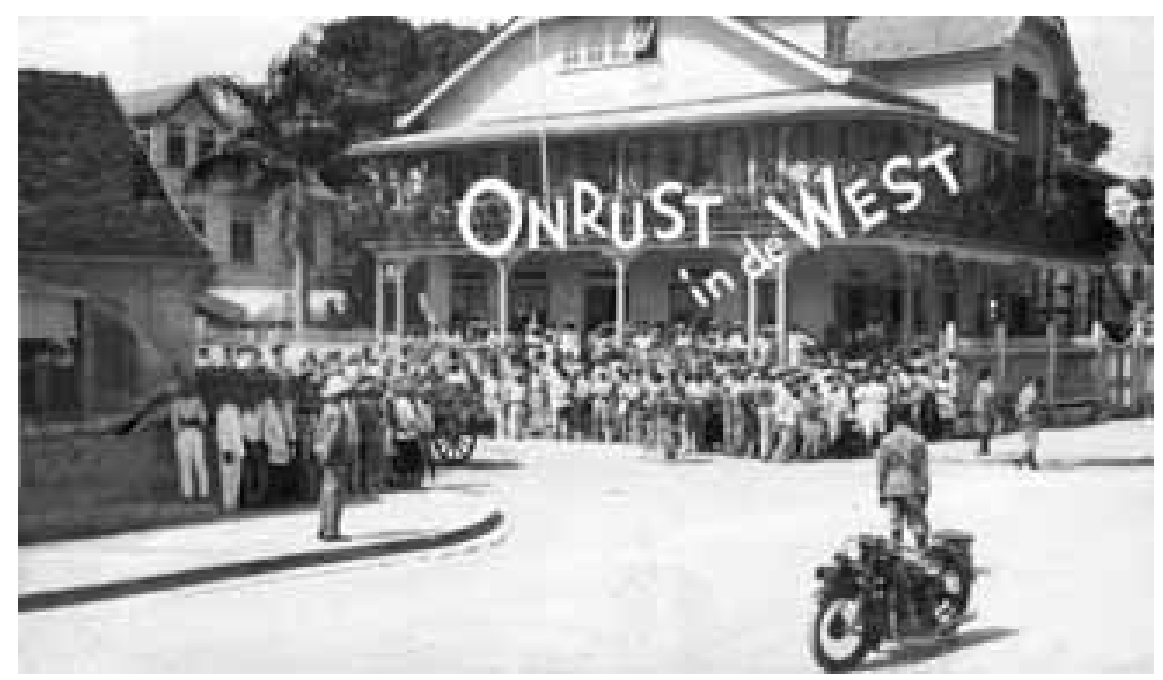

Demonstratie ter vrijlating van Anton de Kom, 1933.

Het Leven, nr. 10 (1933) 303

orde. Hij is thans bestuurslid van de Sectie Holland van de Liga tegen Imperialisme en het is zeer zeker te verwachten, dat hij te Paramaribo actie zal voeren tegen het gezag en vóór het communisme. $^{7}$

Bij De Koms aankomst in Paramaribo werd een grote politiemacht gemobiliseerd. Deze mobilisatie vergrootte uiteraard onbedoeld de aandacht voor de gebeurtenis. Vanaf het moment dat De Kom zich in Paramaribo vestigde, schaduwden de autoriteiten hem permanent. Beperkt in zijn bewegingsvrijheid en zijn mogelijkheden om werk te vinden, besloot De Kom een adviesbureau op te zetten om de veelal analfabete contractarbeiders bij te staan en te onderwijzen over hun rechten. Dit geïmproviseerde bureautje in zijn ouderlijk huis werd het middelpunt voor

7 René Zwaap, 'Anton de Kom als staatsvijand: hoe de CID bijdroeg aan de lancering van "Wij slaven van Suriname"', OSO: Tijdschrift voor Surinamistiek en het Caraïbisch Gebied 29.1 (2010) 49-55 citeert het archief van de Centrale Inlichtingendienst, document 34182 gedateerd 21 december 1932. de klassenstrijd in de kolonie en de confrontaties tussen de arbeidersbeweging en de koloniale politiediensten. Als gevolg hiervan beschuldigde de overheid De Kom van het beramen van een opstand om de Surinaamse koloniale regering omver te werpen. De gouverneur van Suriname liet hem drie maanden in Fort Zeelandia opgesloten zitten. Het fort was een beruchte eeuwenoude vesting die als koloniale gevangenis werd gebruikt. Tijdens zijn detentie escaleerden de demonstraties voor zijn vrijlating; door geweld van de politie vielen er twee doden en vele gewonden. In plaats van De Kom te berechten, besloten de autoriteiten dat hij naar Nederland zou moeten worden verbannen. Dit haalde onmiddellijk de angel uit de straatconflicten.

In 1933, terug in Nederland, maakte De Kom zijn Wij slaven van Suriname af. Het boek beschrijft de misdaden van het koloniale regime en verzet zich tegen de slavenmentaliteit die Surinamers verhinderde om op te staan tegen de Nederlandse autoriteiten. In het boek combi- 
neert De Kom zijn ervaring als activist met zijn kennis van de geschiedenis van Suriname en voegt hij een commentaar toe over de gebrekkige economische ontwikkeling van de Nederlandse kolonie. Na publicatie van Wij slaven in 1934 werd het voor De Kom onmogelijk om nog aan werk te komen. Vanwege zijn betrokkenheid bij het verzet tegen de nazi's en zijn schrijven voor de ondergrondse krant $D e$ Vonk van de Communistische Partij Nederland, werd De Kom uiteindelijk gearresteerd. Hij werd gedeporteerd van Den Haag naar het concentratiekamp Neuengamme in Duitsland en stierf tijdens een dodenmars van daar naar het kamp Sandbostel. Gezien het verloop van De Koms leven en de manier waarop zijn politieke engagement hem keer op keer in de problemen bracht, is het misschien niet eens verwonderlijk dat met name zijn vrouw en kinderen niet onverdeeld positief waren over de rol die de communistische beweging in hun leven speelde.

\section{Het schrijven van Wij slaven}

In de afgelopen tachtig jaar heeft Wij slaven vele antikoloniale en linkse activisten geïnspireerd. Het is een fundamentele tekst geworden voor Surinaams nationalisme waarin de multi-etnische oorsprong van het land en de ervaringen van de verschillende bevolkingsgroepen op een inclusieve manier tot één verhaal worden gesmeed. Het is daarmee een voorbeeld van een vroege onafhankelijke Caribische benaderingen van het eigen verleden. De Nederlandse editie van Wij slaven is nu in zijn twaalfde herdruk, nog afgezien van de roofdrukken uit de jaren zeventig. Sinds de Duitse vertaling in 1935 is het boek ook voor een internationaal publiek beschikbaar. De Duitse vertaling werd gepubliceerd met behulp van communistische uitgevers in Moskou en Zürich. ${ }^{8}$ Een Spaanse vertaling verscheen in Cuba en werd meer recentelijk opnieuw uitgegeven door de Venezolaanse ambassade in Paramaribo. ${ }^{9}$ De Engelse vertaling is nooit gepubliceerd als gevolg van ideologische conflicten tussen de erfgenamen van De Kom en verschillende uitgevers, waarover later meer.

Anton de Kom begon in 1926 met het verzamelen van materiaal voor het boek. In deze periode begaf hij zich in Indonesische nationalistische en linkse kringen in Nederland. Zo was hij in 1927 aanwezig bij de oprichtingsvergadering van de Liga tegen het imperialisme en koloniale onderdrukking. Twee jaar later stond hij op het $18^{\text {de }}$ congres van de Communistische Partij Holland - Centraal Comité (een tijdelijke afsplitsing van de officiële Communistische Partij, onder leiding van David Wijnkoop). Op het congres werd opgemerkt: 'Onze Surinaamse partijgenoot Adek [= Anton de Kom] vestigt de aandacht op de achterstelling der gekleurde rassen. ${ }^{10}$ Hij begon ook te publiceren in de Nederlandse uitgaves De Communistische Gids en De Tribune en The Negro Worker, het blad van de International Trade Union Committee for Black Workers. ${ }^{11}$

8 A. de Kom, Wir Sklaven von Surinam (Moskou: Verlagsgenossenschaft Ausländischer Arbeiter in der UdSSR, 1935); A. de Kom, Wir Sklaven von Surinam (Zurich: Ring, 1936).

9 A. de Kom, Nosotros, esclavos de Suriname (La Habana: Casa de las Americas, 1981); A. de Kom, Nosotros, esclavos de Suriname (Catedra Libre de Simón Bolivar, 2008).

10 Para, 'Anton de Kom', 105.

11 Idem. 
De Nederlandse Centrale Inlichtingendienst meldde over De Kom dat hij lezingen gaf over uiteenlopende onderwerpen, waaronder racisme in de Verenigde Staten. In De Communistische Gids pleitte hij voor Indonesisch-Surinaamse eenheid tegen onderdrukking, in lijn met de leus van de CPN voor de koloniën: 'Los van Holland $-\mathrm{Nu}^{12}$ In zijn artikel in The Negro Worker, dat bijna gelijktijdig werd gepubliceerd met Wij slaven, was De Kom duidelijk wat betreft zijn positie ten opzichte van de onafhankelijkheidsstrijd. Het artikel besluit met de zin: 'Close ranks in struggle for the emancipation of the colonial toilers! Demand the independence of Dutch Guiana! ${ }^{13}$

De Kom combineerde in Wij slaven de politieke inspiratie van de anti-imperialistische en communistische beweging met de voortlevende herinnering aan de slavernij. Dit leidde tot een geheel nieuwe kijk op de geschiedenis die in de orale tradities van de nazaten van de slaafgemaakten deels nog bestond, maar die niet eerder op schrift was gesteld. Daarnaast was abolitionistische literatuur van grote invloed op zijn werk. Veel van de voorbeelden van wreedheden jegens slaafgemaakten komen uit het werk van de Nederlandse abolitionistische auteur Juliën Wolbers. De Kom raadpleegde ook John Gabriel Stedmans achttiende-eeuwse reisverslag, evenals een achttiendeeeuwse koloniale geschiedenis geschre-

12 Van Suchtelen, 'De Kom'.

13 A. de Kom, 'Starvation, misery and terror in Dutch Guyana', The Negro Worker (juni 1934) 19-20. ven door Jan Jacob Hartsinck. ${ }^{14}$ Meer dan de negentiende-eeuwse abolitionistische auteurs toont De Kom een talent voor het integreren van de verhalen van mensen die slachtoffer werden van de Europese kolonisatoren. ${ }^{15}$ Daarbij breekt De Kom 'de koloniale pen' die het schrijven over Suriname tot dan toe had gekenmerkt. $^{16}$

In Wij slaven beweegt De Kom van het tijdperk van de slavernij (tot 1863) naar zijn eigen tijd en levert hij commentaar op de ontwikkelingen in de Surinaamse arbeidersbeweging en de onstuimige gebeurtenissen rond zijn eigen terugkeer naar Suriname. Hij stelt in het boek dat de slavenmentaliteit, die in zijn ogen debet is aan de voortdurende achterstelling van niet-witten in de kolonie, een erfenis is van de slavernij. De laatste hoofdstukken van het boek gaan over zijn eigen ervaring als activist in Suriname en de problemen die hij ondervond in het smeden van een proletarische eenheid tegen het kolonialisme.

$\mathrm{Al}$ sinds het boek werd gepubliceerd is er een debat over de vraag of de uitgever te gemakkelijk is overgegaan op (zelf-) censuur of heeft toegegeven aan verzoeken van de politie om passages in het boek te veranderen. Nog voordat het

\footnotetext{
14 Julien Wolbers, Geschiedenis van Suriname (Amsterdam 1970); Jan Jacob Hartsinck, Beschryving van Guyana, van de Wildekust in Zuid-Amerika (Amsterdam: Gerrit Tielenburg, 1770); John Gabriel Stedman, Narrative of a five years expedition against the revolted negroes of Surinam (Londen: J. Johnson \& J. Edwards, 1796); Wim Hoogbergen, 'Wat las De Kom voor "Wij slaven van Suriname", OSO: Tijdschrift voor Surinamistiek en Het Caraïbisch Gebied 29.1 (2010), 56-73, aldaar 63-64. 15 Hoogbergen, 'Wat las De Kom', 65-66.

16 G.J. Oostindie, 'Kom, Cornelis Gerhard Anton de (1898-1945)' in: Biografisch Woordenboek van Nederland, vol. 5 (2002).
} 
boek werd gepubliceerd, volgde de CID nauwgezet het schrijfproces. Op een dag was er zelfs een inval in De Koms huis en groeven de autoriteiten in zijn tuin om het manuscript te vinden. ${ }^{17}$ Uit een lezing van bronnen van de CID concludeert René Zwaap dat de dienst hoofdzakelijk bezwaar maakte tegen passages die foltering op de plantages en seksueel misbruik van slaafgemaakte vrouwen beschrijven. Ondanks hun bezwaren tegen delen van het boek lijkt het niet waarschijnlijk dat de inlichtingendienst of de politie directe censuur van passages in het boek hebben geëist. Sommige paragrafen werden echter wel gewijzigd. In de eerste editie voegt de uitgever bij wijze van toelichting een cryptisch zinnetje toe:

In verband met de opmerkzaamheid van zekere zijde voor dit boek betoond, achtten de uitgevers het noodzakelijk, teneinde de ongestoorde verspreiding van het werk te verzekeren, om, na overleg met den schrijver enkele wijzigingen in de tekst aan te brengen, waardoor echter de waarde van het boek niet werd aangetast. ${ }^{18}$

Het boek werd snel in het Duits vertaald door Augusta de Wit, een hoogopgeleide, op Sumatra geboren publicist en vertaler die in verschillende revolutionaire socialistische bewegingen actief was geweest en in 1916 lid werd van de Sociaal-Democratische Partij, de voorloper van de communistische partij. ${ }^{19}$ De communistische schrijver Jef Last, een vriend van De Kom

17 Zwaap, 'Anton de Kom als staatsvijand', 49.

18 A. de Kom, Wij slaven van Suriname (Amsterdam: Contact, 1934).

19 Jan Gielkens, 'Wit, Anna Augusta Henriette de' in: Biografisch Woordenboek van het Socialisme en de Arbeidersbeweging in Nederland, vol. 4 (1990) 219-222. die hem vaak had aangemoedigd om zijn boek uit te geven, hielp bij de publicatie van de Duitstalige versie. Een agent van de CID merkte op dat De Kom in een van zijn toespraken zei dat door de 'vriendelijke tussenkomst van Sovjet-Rusland' zijn boek snel gepubliceerd zou worden. ${ }^{20}$ Reeds in 1935 werd het boek uitgegeven door een uitgeverij voor buitenlandse arbeiders in Moskou. ${ }^{21}$ Een jaar later bracht een communistische uitgever een tweede, ongewijzigde, editie uit. ${ }^{22}$ Als gevolg van de opkomst van het fascisme en de Tweede Wereldoorlog hebben historici nog niet kunnen achterhalen in hoeverre het boek in het Duits ook verspreid is en hoe het is ontvangen door het Duitstalige publiek. Na de Tweede Wereldoorlog werd de belangstelling voor Wij slaven nieuw leven ingeblazen door linkse Surinaamse studenten aan de Universiteit Leiden. Hun kopie van het boek vormde vermoedelijk ook de basis voor de Spaanstalige editie op Cuba. Van deze Spaanse editie van 1981 merkten letterkundigen op dat deze 'met enthousiasme is ontvangen door Spaanstalige lezers'. ${ }^{23}$

\section{Overstemmende stilte}

Kunnen we een oprechte communistische inspiratie in Wij slaven zien, en is het waarschijnlijk dat dit voor De Kom een integraal onderdeel van de tekst was? Of hebben partijideologen passages toege-

20 Zwaap, 'Anton de Kom als staatsvijand', $5^{1}$ citeert Centrale Inlichtingendienst, documentnummer 0363a, gedateerd 15 juni 1933.

21 De Kom, Wir Sklaven (1935).

22 De Kom, Wir Sklaven (1936).

23 Ineke Phaf, G. J. van Exel en Maureen Berkel, 'Caribbean imagination and nation-building in Antillean and Surinamese literature', Callaloo 34 (1988) 148-171. 
voegd, die wellicht later door de uitgever weer zijn afgezwakt? Het boek zelf bestaat uit vier zeer ongelijke delen, die sterk in lengte, inhoud en stijl variëren. De ideologische inkadering van Wij slaven is niet altijd expliciet, maar lijkt door het boek heen wel consistent te zijn. Bij wijze van inleiding schrijft De Kom een kort eerste hoofdstuk getiteld "Sranang", ons vaderland'. Dit is samen met de afsluitende woorden van het boek het bekendste deel. Het bestaat uit slechts een paar pagina's en is op het eerste gezicht een situatieschets voor de rest van Wij slaven. De pagina's zijn gericht op het overtuigen van de lezer van de natuurlijke schoonheid van het land en het gewelddadige contrast met de Europese pogingen tot de penetratie van 'moeder Sranan'. ${ }^{24}$

In de inleiding verwijst De Kom naar het werk van Magdalena Paz, die net rond deze tijd haar boek Frère Noir had gepubliceerd. ${ }^{25}$ Ook al spelt hij haar naam verkeerd, de verwijzing naar Paz is erg relevant om een beeld te krijgen van De Koms denken en de keuzes die hij heeft gemaakt bij het schrijven van zijn boek. Paz was sympathisant van Leon Trotski, een Russische revolutionair die in oktober 1917 een belangrijke rol speelde en zich later toelegde op de organisatie van het Rode Leger. Trotski raakte als rijzende ster binnen de Sovjet-Unie in conflict met Stalin. Tijdens de stalinisatie van de communistische partijen werden hij, zijn sympathisanten en andere dissidenten binnen deze partijen verguisd en vervolgd. Paz was tijdens de stalinisatie van de internationale communistische beweging uit de Franse Communistische Partij

24 De Kom, Wij slaven, 13-15.

25 Dit argument wordt ook besproken in FatahBlack, 'Genderrollen', 3-7.

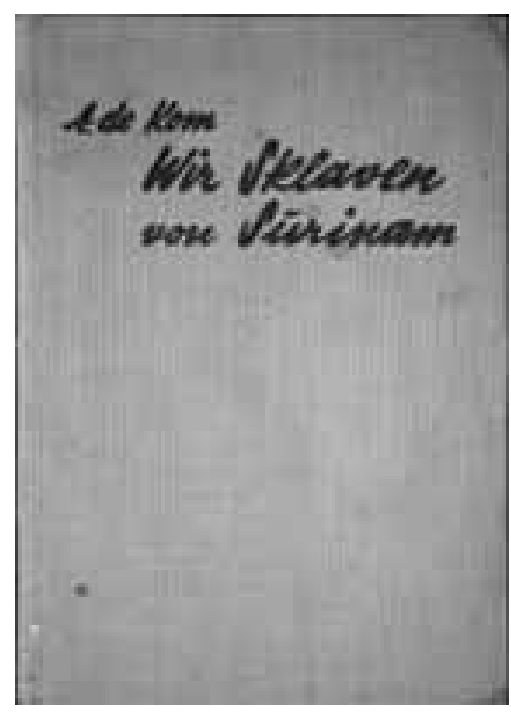

Omslag van de Duitse vertaling van Wij slaven, uitgegeven in de Sovjet-Unie.

gezet. Het feit dat De Kom haar werk lijkt te hebben gelezen en het zo sterk in gedachten had bij het schrijven van deze belangrijke inleidende paragraaf is opvallend. Het is ook opvallend dat hij hier niet naar politieke theorie verwijst, maar, hoewel Paz expliciet een communist en een feminist was, dat de De Kom hier een roman citeert die racisme thematiseert.

Het volgende deel van Wij slaven, getiteld 'Het tijdperk der slavernij', is het hart van het werk en is voor veel lezers vermoedelijk het meest sprekende en meeslepende deel. De tekst bestaat uit een grotendeels chronologische geschiedenis van Suriname en onderstreept het cynisme, de brutaliteit en het geweld waarmee kolonisatie gepaard ging. De periodisering van de ontwikkeling van het kolonialisme en de relatie tot het kapitalisme is een belangrijk onderdeel van de structuur van het boek en wordt geleverd door De Koms lezing van Werner Sombarts Der Bourgeois (1920). Sombarts bij- 
drage aan het begrip van de kapitalistische samenleving heeft zijn sporen nagelaten in het denken van veel intellectuelen in de periode waarin De Kom schreef. De Kom geeft een lang citaat uit Sombarts paragraaf over Freibeuter in het hoofdstuk over de Grundtypen des kapitalistischen Unternehmertums. Hier beargumenteert Sombart dat de Europese expedities, die traditioneel begrepen worden als 'ontdekkingsreizen', gezien zouden moeten worden als een vorm van piraterij. Sombart bespreekt de reizen naar het mythische El Dorado - in het binnenland van Guyana - in dezelfde paragraaf als waar hij naar de Italiaanse prinsen van het renaissance-tijdperk verwijst. De Kom verwijderde tussenliggende alinea's waardoor hij een tekst opbouwt die de essentie van Sombart goed samenvat en tegelijkertijd de historische rol van Guyana in de geboorte van het kapitalisme benadrukt. ${ }^{26}$

Op deze manier heeft De Kom aan het begin van zijn boek kapitalisme en kolonialisme in nauwe samenhang gebracht. Hij benadrukt specifiek de agressieve aard van wat marxisten vaak de 'primitieve accumulatie van het kapitaal' noemen. De Kom volgt daarna de canonieke chronologie van de geschiedenis van Suriname vanaf het moment van 'ontdekking' tot het begin van de Nederlandse aanwezigheid. Door de chronologie heen weeft hij scènes aan boord van slavenschepen en op plantages. In de rest van dit hoofdstuk ontbreken verwijzingen naar communisten of marxistische denkers. Het hoofdstuk volgt echter op een impliciete manier het communistische denken door een maatschappelijke verdeling langs klassenlijnen als belangrijk organisato-

26 Werner Sombart, Der Bourgeois (München / Leipzich 1920) 90-101. risch principe te gebruiken. In de beschrijving van de chronologie is hij scherp over de hypocrisie van de eurocentrische interpretaties van de Verlichting en de Franse Revolutie. ${ }^{27}$ In de afsluitende paragrafen van het hoofdstuk moedigt De Kom de lezer aan om een klasse-interpretatie van de afschaffing van de slavernij te volgen: terwijl de juridische bovenbouw misschien veranderde, was de onderdrukking en uitbuiting niet verdwenen en de 'mentaliteit der heersende klasse die dezelfde bleef. ${ }^{28}$ Hij geeft een economische verklaring voor de verwoesting die de afschaffing van de slavernij volgde en schrijft: 'Het kapitaal verdween naar het buitenland'. ${ }^{29}$ De wijzigingen ten opzichte van het roofzuchtige kapitalisme van Sombarts Freibeuter-fase met het kapitalisme dat de slavernij afschafte en waarin industriële productie dominant werd, blijft onbesproken. Een communistische interpretatie van deze nieuwe periode, zoals bijvoorbeeld het imperialisme, is verrassend genoeg afwezig.

Het derde deel van het boek is getiteld 'Het tijdperk der "vrijheid"' en draagt veel duidelijker de sporen van een marxistische interpretatie van de geschiedenis. ${ }^{30}$ Hier vinden we ook een verre echo van de Russische Revolutie, maar alleen als een stilte in zijn tekst. De Kom legt uit hoe door het machtsverschil in de kolonie de post-slavernijcontracten tussen werknemers en bedrijven alleen in naam 'vrij' zijn. Hij noemt de Surinaamse arbeider een 'proletariër, die volkomen bezitloze arbeider, die niets dan zijn arbeidskracht heeft te verkopen.' ${ }^{31}$ Hij stelt dat 'staat' en

\footnotetext{
27 De Kom, Wij slaven, 81.

28 Ibidem, 106.

29 Ibidem, 107.

30 Ibidem, 109.

31 Ibidem, 111-112.
} 
'kapitaal' samenwerken om de arbeiders uit te buiten. Voor De Kom is 'de neger' 32 een 'bezitloze proletariër'. ${ }^{33}$ Terwijl deze redenering heel duidelijk geïnspireerd is door communistische concepten en een marxistisch begrip van maatschappelijke structuren, voegt De Kom ook de koloniale dimensie toe: 'We vragen aan Nederlandse vakbestuurders hoe dergelijke voorschriften hun smaken als voorbeeld voor een collectieve arbeidsovereenkomst voor blanken.' ${ }^{34}$ De Kom bespreekt de verschillende groepen van contractarbeiders die na de slavernij naar Suriname werden gebracht en hij schenkt hoofdzakelijk aandacht aan de onderdrukte positie waarin ze zich bevinden. Klasse en uitbuiting zijn zijn lens. Een voorbeeld hiervan is zijn interpretatie van de criminaliteit onder Javanen, een van deze migrantengroepen. De Kom interpreteert de criminaliteit onder deze groep direct als gevolg van de erbarmelijke omstandigheden waarin ze zich bevond. ${ }^{35}$

In hoeverre wijst dit op een communistische inspiratie bij het schrijven van het boek? De biografen Alice Boots en Rob Woortman stellen dat de communistische sympathie van De Kom minimaal was. Ze illustreren dit aan de hand van concrete voorbeelden die inderdaad duidelijk maken dat enkele sterk ideologisch getinte delen door anderen aan de tekst zijn toe-

32 De Kom gebruikt vaak de term 'creolen' om AfroSurinamers als groep mee aan te duiden. De denigrerende lading van 'neger' wordt hier door De Kom waarschijnlijk bewust ingezet om het cynisme waarmee zwarte contractarbeiders na afschaffing van de slavernij werden behandeld te benadrukken.

33 De Kom, Wij slaven, 113 .

34 Ibidem, 114.

35 Ibidem, 125 . gevoegd. ${ }^{36}$ Als we echter niet alleen op zinsniveau kijken, maar ook de overkoepelende argumenten van de tekst bezien, blijkt dat het idee van enkel door buitenstaanders toegevoegde communistische stellingnames niet klopt. De argumenten, de gekozen periodisering en de nadrukken in de tekst wijzen in de richting van een schrijver die aan de hand van een communistische inspiratie een nieuwe geschiedenis heeft willen schrijven. Het lijkt er op dat het oordeel van de biografen onder andere is ingegeven door een poging om De Kom respectabel te maken door hem los te koppelen van wat nu wordt gezien als een radicale en irrationele politieke beweging. De Koms nadruk op klasse en impliciet ook op onafhankelijkheid en revolutie laten zien dat zijn engagement met het communisme diepgaander was. De disclaimer van de uitgever is een slecht verstopte suggestie dat hij en De Kom zich onderworpen hebben aan een vorm van zelfcensuur met als doel de verspreiding van het boek te garanderen.

Boots en Woortman zien De Kom in de eerste plaats als een literaire figuur en bagatelliseren de politieke en ideologische inspiratie voor het schrijven van Wij slaven. Dat de wijzigingen in de gepubliceerde editie het resultaat zijn van een samenwerking tussen de uitgever en de auteur lijkt zeker te kloppen en de beschuldigingen in de communistische pers dat het boek zwaar gecensureerd zou zijn lijken inderdaad overtrokken. ${ }^{37}$ Dat doet

36 Alice Boots en Rob Woortman, 'De geschiedenis van een manuscript. De wording van Wij slaven van Suriname van Anton de Kom', OSO: Tijdschrift voor Surinamistiek en het Caraïbisch gebied 29.1 (2010) 3048.

37 Ibidem. 
echter nog niet af aan het feit dat de uiteindelijke publicatie een duidelijk mildere toon heeft dan de pre-publicaties in de linkse en communistische pers en dat alle verwijzingen naar de onafhankelijkheid van Suriname zijn verdwenen. Het is echter niet zo dat we hieruit zouden moeten opmaken dat De Kom eigenlijk helemaal de onafhankelijkheid van Suriname niet nastreefde. Het streven naar onafhankelijkheid is impliciet namelijk nog wel in de tekst aanwezig. De expliciete verwijzingen zijn verdwenen, maar de wens voor onafhankelijkheid is hoorbaar verstilt door zelfcensuur. Een voorbeeld hiervan vinden we in het deel waar De Kom betoogt dat arbeiders moeten opstaan en werken aan 'een groot plan van nationale reconstructie'. De natie die hij hier 'Ons vaderland' noemt is niet het Koninkrijk Nederland, maar zijn geliefde Suriname, of 'Mijn Sranang,. ${ }^{38}$ Zonder op te roepen tot onafhankelijkheid, is onafhankelijkheid wel een voorwaarde om zijn plan überhaupt uit te kunnen voeren.

De vraag over zelfbeschikking ligt vooral op tafel als De Kom de 'autonomie' van Suriname in het Nederlandse koninkrijk bespreekt. Hij wijst erop dat de term 'autonomie' misleidend is door haar te vergelijken met het verschil tussen een arbeidersraad en een Raad van Arbeid. ${ }^{39}$ Deze verwijzing is vooral begrijpelijk voor degenen die bekend waren met de debatten in de linkse bewegingen in de nasleep van de Russische Revolutie. Onder de leuze 'Alle macht aan de Sovjets [Russisch voor raden]', had Lenin tijdens de revolutie gepleit voor een machtsgreep door de over-

38 De Kom, Wij slaven, 154.

39 Ibidem, 115. legorganen van arbeiders. Deze zelforganisatie en tegenmacht waren een schrikbeeld voor gematigde socialisten die zich wilden beperken tot overleg en invloed via overlegorganen. De Kom stelt dat de Raad van Arbeid is als de autonomie van Suriname: het lijkt op iets dat in communistische ogen goed is (arbeiderszelfbestuur), maar het is verre van dat. De Kom geeft een overzicht van de samenleving die begrijpelijk was voor een publiek dat bekend was met de communistische manieren van denken en interpreteren van de sociale dynamiek. Hier hoort ook bij dat de tactieken van de sociaaldemocraten van Suriname worden bekritiseerd, en specifiek de Surinaamse vakbondsbestuurder Doedel en zijn pogingen om de koloniale autoriteit tegemoet te komen in plaats van een compromisloze houding aan te nemen.

In tegenstelling tot Doedel hield De Kom de Surinaamse bevolking voor: 'gij zult in armoede en ellende blijven leven, zolang gij geen vertrouwen hebt in uw eigen proletarische eenheid. ${ }^{40}$ Wat nodig was, was dat de 'proletariërs tot strijdvaardig klassebewustzijn komen'. ${ }^{41}$ Dit geloof en de daaropvolgende strijd zou moeten resulteren in 'collectieve grootbedrijven met moderne outillage in handen van de arbeiders van Suriname'. ${ }^{42}$ De Kom verwerpt de zorgvuldige methoden van de sociaaldemocraten, pleit voor een militant klasbewustzijn, dat dan snel gevolgd wordt door een moderniseringsplan van industrieën in de handen van de arbeiders. De daad van het onteigenen van de grote industrieën, ze in de handen van de

\footnotetext{
40 Ibidem, 154.

41 Ibidem.

42 Ibidem.
} 
arbeiders over laten gaan en de confrontatie met de staat (die hij eerder al handlangers van de kapitalisten heeft genoemd) vermijdt De Kom echter. Dit is een gat in zijn redenering en een stilte in zijn verhaal. De stilte is vooral voor de hand liggend, omdat het verhaal er duidelijk naar opbouwt. In zijn afwezigheid is de echo van de Russische Revolutie luid en duidelijk in dit derde deel van het boek. Voor de communistische lezer, ingevoerd in het idioom van die tijd is het echter duidelijk geweest hoe de overgang van militant klassebewustzijn tot zelfstandige werkers zou moeten plaatsvinden. De Russische Revolutie was een voorbeeld voor het invoeren van communistisch beleid. Het traject dat De Kom voorstelt voor Suriname is er een van een communistische antikoloniale revolutie waarin de $\mathrm{Su}-$ rinaamse arbeider de economie uit de handen van de kapitalisten neemt en de kapitalistische staat neutraliseert.

In het laatste deel van het boek, 'Weerzien en afscheid', verhaalt De Kom over zijn ervaring in Suriname aan de hand van zijn uit de hand gelopen aankomst, zijn activisme, de arrestatie en tot slot de deportatie. Hij laat niet na te vermelden dat hij bij aankomst door de bevolking zowel als communist en als Messias werd gezien. ${ }^{43}$ De Kom beschrijft zijn activiteiten in de kolonie en het belang dat hij hechtte aan interetnische solidariteit:

Indianen, bosnegers, creolen, BritsIndiërs, Javanen, er waren dagen, terwijl de motorbrigades der politie buiten op straat circuleerden, dat meer dan vijftienhonderd aan mijn tafel verschenen,

43 Ibidem, 158-159. waarvan sommigen zeven tot acht dagen gereisd hadden om mij te spreken. ${ }^{44}$

In dit laatste deel blijft De Kom vasthouden aan de analyse die hij in de rest van het boek maakte, al lijkt hij bij het beschrijven van zijn eigen ervaringen meer op zijn hoede. Hij laat in het midden hoe hij had willen bijdragen aan het plan dat hij in het voorgaande deel ontvouwde en hij is er vlug bij om duidelijk te maken dat hij weigerde om gesmokkelde wapens van de 'Djoeka's' (Okanisi) in ontvangst te nemen. 'Het was mij te doen om organisatie, niet om een bloedbad,' schrijft hij. ${ }^{45}$ Zijn stilte over de noodzakelijke revolutie wordt hier dus gevolgd door een regelrechte ontkenning een gewelddadige revolutie te willen bewerkstelligen. Het zou ook kunnen dat De Kom zelf, na te hebben gezien met welk geweld de koloniale staat optrad (bij de demonstraties voor zijn vrijlating waren twee doden gevallen), was gaan twijfelen over een revolutionair pad naar de onafhankelijkheid. Maar als dat zo is gaat het uitdrukkelijk om een twijfel

44 Samen met de staatkundige dekolonisatie is men in toenemende mate ook de categoriseringen van de koloniale staat gaan verwerpen. In sommige gevallen is dit bij een semantische verzetsdaad gebleven. Opvallend is dat Anton de Kom in zijn boek uitdrukkelijk spreekt van Indonesiërs terwijl de onafhankelijkheid van wat destijds Nederlands-Indië genoemd werd nog in het verschiet lag. In veel gevallen nam De Kom wel de koloniale categorieën over. In plaats van 'indianen' gebruikt men tegenwoordig liever de term inheemsen met verwijzing naar de specifieke etniciteit. De term 'bosneger' wordt nu meestal vervangen door marron, eveneens met verwijzing naar de marronnaam van de specifieke marrongroep, zoals de Okanisi of Saamaka. In plaats van de enigszins verwarrende term 'creolen' spreekt men nu vaak van Afro-Surinamers. De koloniale termen 'Brits-Indiër' en 'koelie' zijn vervangen door hindostaan, wat duidt op een afkomst uit de regio Hindostan. De Kom, Wij slaven, ${ }_{161 .}$

45 De Kom, Wij slaven, 164. 


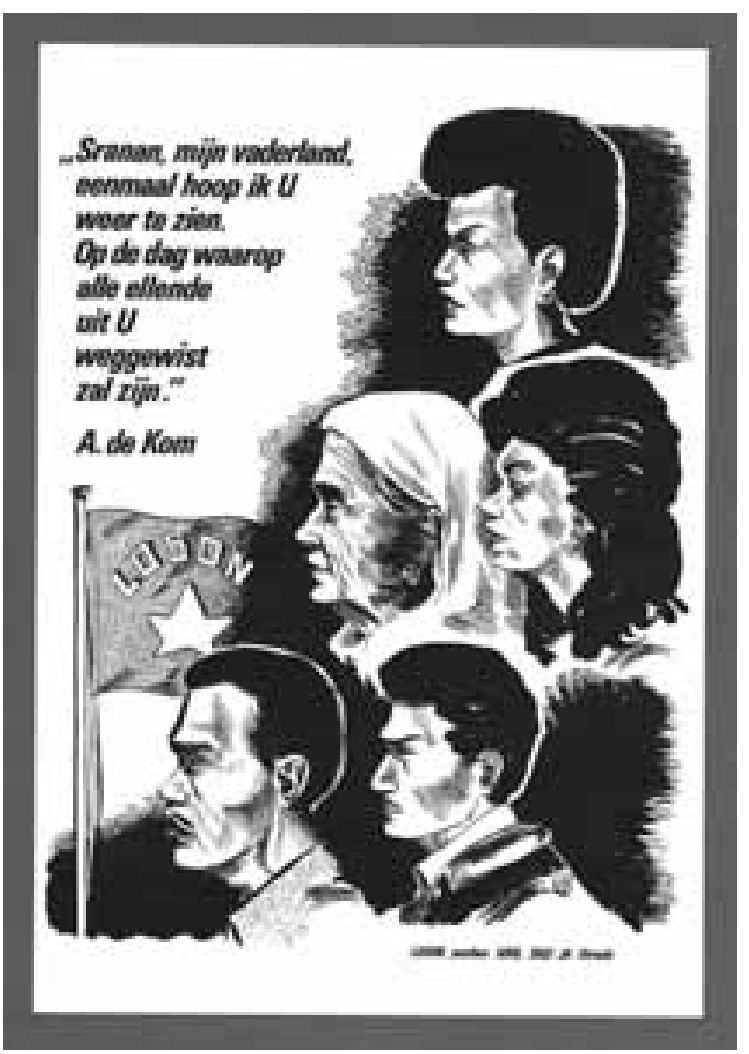

Poster van de Surinaams-Nederlandse strijdorganisatie LOSON. 1980-1985. Internationaal Instituut voor Sociale Geschiedenis, Amsterdam

en geen afkeer van zijn eerdere, wellicht stelligere, communistische en anti-imperialistische politiek. Dat zien we bijvoorbeeld aan zijn herhaaldelijke verwijzing naar het bloedbad tijdens de werklozenopstand van 1931 als 'Rode Oktober' waarover De Kom oordeelt dat dit 'nodig' was om van de regering concessies af te dwingen. ${ }^{46}$

\section{Deletie}

In de verschillende publieke herinneringen aan Anton de Kom blijven zijn com-

46 Ibidem, 163-164. munistische sympathieën bewust onbesproken. De inspiratie die De Kom uit het communisme en de Russische Revolutie heeft gehaald en aan de hand waarvan hij over een toekomst voor Suriname probeerde na te denken, wordt zelden onderkend of herinnerd. De term 'deletie' gebruik ik zoals in de Angelsaksische literatuur van de critical theorists soms de term erasure wordt gebruikt. De term erasure dient om het proces aan te duiden waarmee perspectieven en verhalen die niet voldoen aan het idee dat de geschiedenis wordt gemaakt door superieure en daadkrachtige witte hetero mannen uit het publieke geheugen worden verwijderd of niet relevant worden geacht voor bestudering door wetenschappers. ${ }^{47}$ 'Rode deletie' is deels het resultaat van de neiging tot het schrijven van overwinnaarsgeschiedenis. De historische nederlaag van het communisme in de twintigste eeuw heeft er toe geleid dat een communistische kijk op het verleden in onbruik is geraakt. De nederlaag van het communisme heeft ook geresulteerd in een zekere schaamte over communistische invloeden op levens die vandaag de dag worden gemonumentaliseerd. Drie groepen actoren hebben ieder een eigen niet-communistische herinnering aan het leven en werk van De Kom ontwikkeld. Allereerst de Surinaamse staat die na de coup in 1980 onder bestuurlijke leiding stond van Desi Bouterse en ideologisch werd aangevoerd door Henk Herrenberg. Ten tweede, de familie van Anton de Kom die, ondersteund door de biografen Rob Woortman en Alice

47 Anthony Bogues, 'C.L.R. James and W.E.B. Du Bois: Black Jacobins and Black Reconstruction, Writing heresy and revisionist histories' in: Abigail B. Bakan en Enakshi Dua ed., Theorizing anti-racism: Linkages in marxism and critical race theories (Toronto 2014) 148183. 
Boots hun voorvader als een literaire held verheerlijken. Ten slotte de postmoderne school van dekoloniale activisten die De Kom als inspirator en voorloper zien, maar hem gelijktijdig probeerden in te passen in een anticommunistische theorie.

In de jaren tachtig is De Kom uitgegroeid tot nationale held in Suriname. Tot die tijd was hij vooral bekend in activistische kringen van Surinamers in $\mathrm{Ne}$ derland. De Surinaamse militaire regering die na de staatsgreep van 25 februari 1980 aan de macht kwam verhief De Kom tot nationale held en ontwikkelde zo een door de staat gesteunde herinnering aan De Kom. Het regime presenteerde De Kom als een nationalist en antikoloniale denker die de etnische scheidslijnen oversteeg. Zijn oproerige communisme vond alleen in de eerste fase na de coup nog weerklank. Toen na de Decembermoorden de linkse ideologen en activisten geen rol meer speelden in het formuleren van het beleid van het Bouterse regime werd door de overheid vooral nog De Koms Surinaamse nationalisme en vakbondsactivisme benadrukt. ${ }^{48}$ De term 'revolutionair' waarmee onder andere de in Algerije opgeleide Henk Herrenberg De Kom betitelde, diende als een verwijzing naar bijvoorbeeld Che Guevara en voorstanders van een door het leger geleide machtsovername. In de regio dienden Castro's Cuba en Bishops Granada als voorbeelden voor de nieuwe machthebbers. In de geest van nationalistische toeeigening kwam het portret van De Kom op de bankbiljetten van de Republiek te staan.

De politiek in Suriname had inmiddels al een extreem gewelddadig karakter gekregen nadat in de nacht van 6 december

48 Boots en Woortman, Anton de Kom, hfst. 18.
1982 een groep van 15 mannen (journalisten, vakbondsleden en advocaten) zonder proces, naar verluidt tijdens een ontsnappingspoging werden doodgeschoten. De vijftien waren gevangen gezet op beschuldiging van voorbereiding van een door de CIA gesteunde couppoging. Na de Decembermoorden verbraken de ideologische linkse organisaties hun banden met het militaire regime, maar De Kom bleef als symbool voor nationale onafhankelijkheid en economische ontwikkeling gehandhaafd. De Surinaamse overheid maakte op instigatie van Herrenberg De Kom een symbool van onafhankelijke intellectuele prestatie door de universiteit in Suriname om te dopen tot Anton de Kom Universiteit. ${ }^{49}$ Theo Para schreef hierover scherp dat

het morele gezag van een vooraanstaand vrijheidsstrijder van Suriname en verzetsheld van Nederland was geleend om aan een antidemocratische, quasi-academische constructie de schijn van nationale bevrijding te verlenen. Geen beter middel om de nagedachtenis van een held te bezoedelen dan de propagandistische annexatie door een misdadig regime. ${ }^{50}$

De tweede deletie van het communisme van De Kom komt van zijn familie in Nederland. Deze deletie kan worden herleid naar Petronella Borsboom, de vrouw van De Kom, die na de herontdekking van het werk van haar echtgenoot uitdrukkelijk 'die vuile politiek' de schuld gaf van de dood van haar man en de misère in haar leven. ${ }^{51}$ En tot op zekere hoogte had ze

49 Ibidem, 390-391, 397.

50 Para, 'Anton de Kom'.

51 Boots en Woortman, Anton de Kom, $35^{0 .}$ 
natuurlijk gelijk. Haar man heeft haar en de familie in grote moeilijkheden gebracht door zich zo duidelijk tegen de Nederlandse koloniale macht uit te spreken. Zijn activisme tijdens de Duitse bezetting kostte hem zijn leven. Het is daarom begrijpelijk dat de familie een moeilijke relatie heeft met de herinnering aan De Koms betrokkenheid bij de communistische beweging. Hij zou niet uit Suriname en later naar een Duits concentratiekamp gedeporteerd zijn als hij stil was geweest en thuis was gebleven om met de kinderen te spelen. De dubbele afwijzing van zowel autoritarisme als activisme door de familie kan worden verklaard uit het trauma dat de familie heeft geleden. De rol van de familie bij het vormen van het erfgoed van De Kom heeft echter geleid tot de huidige deletie van zijn communistische verleden. Vooral Judith de Kom, dochter van Anton is vastberaden gaan vasthouden aan het idee dat de activiteiten en publicaties betreffende De Kom zonder 'politiek' zouden moeten zijn. Ze speelde een centrale rol in de boycots door de familie van politiek getinte evenementen en publicaties. Haar rol lijkt wegens ouderdom minder prominent geworden te zijn. ${ }^{52}$

De deletie door de nabestaanden van De Kom wordt de laatste jaren geschraagd door de rijke en uitstekend onderzochte biografie van De Kom van Alice Boots en Rob Woortman. De nadruk in de biografie ligt op de literaire kwaliteiten van Wij slaven, evenals ongepubliceerd werk van De Kom en put uit herinneringen van de kinderen van De Kom aan hun vader. In het laatste deel van de biografie proberen de auteurs de verschillende manieren waarop De Kom als figuur door politieke bewe-

$5^{2}$ Ibidem, 419-420. gingen en de Surinaamse staat is aangewend te deconstrueren. ${ }^{53}$ De auteurs gaan zover te suggereren dat De Kom geen communist was omdat hij geen lid was van de Nederlandse communistische partij. De biografen stellen verder dat de communisten het werk van De Kom een richting gaven die hij niet wilde, en dat de openlijk-ideologische paragrafen in de tekst niet door De Kom zelf waren geschreven. De uitwerking van de biografie is goed terug te zien in een publiekshistorische digitale tentoonstelling die UvAstudenten maakten over De Kom. Op de website staat dat hij 'communistische vrienden' had en wordt de vraag gesteld of hij een 'staatsgevaarlijke communist' was. Een antwoord op de vraag blijft uit, maar de tekst die volgt nijgt naar een ontkenning en benadrukt vooral de moeilijke financiële positie waarin de familie terecht kwam na publicatie van Wij slaven. ${ }^{54}$

Het feit dat er nog altijd, anders dan sommige online zoekmachines beweren, geen Engelse vertaling van Wij slaven beschikbaar is, is een direct gevolg van de wens van de erfgenamen om het politieke verleden van De Kom uit te wissen. ${ }^{55} \mathrm{Er}$ zijn verschillende pogingen gedaan om een Engelse vertaling te maken, maar tot nu toe zijn slechts fragmenten door de vertaler gepubliceerd. ${ }^{56}$ Een poging van het Koninklijk Nederlands Instituut voor Caraïbische en Zuidoost-Aziatische Stu-

53 Ibidem, 317-361.

54 Website: Anton de Kom, http://www.antondekom.humanities.uva.nl/activist/ (geraadpleegd maart 2017).

55 Het is enkele malen bijna tot publicatie gekomen. De publicaties zijn daarom steeds wel aangemeld, waardoor ze in catalogi terecht zijn gekomen. 56 A. de Kom, 'From: We Slaves from Surinam', Callaloo: a Journal of African-American and African Arts and Letters 21.3 (1998) 667-672. 
dies (KITLV) werd door de familie geblokkeerd omdat ze vonden dat het niet goed zou zijn om het erfgoed van 'Adek' te publiceren bij een instelling met zijn wortels in het koloniale tijdperk. ${ }^{57}$

In 2012 nam Antonio Carmona Baez, destijds docent Politieke Wetenschappen en socialist, het initiatief om de Engelse vertaling van het werk van De Kom opnieuw ter hand. Als basis dienden de proefdrukken uit 1990 van een ongepubliceerde vertaling die Arnold J. Pomerans in 1986 in opdracht van de erfgenamen maakte. Deze publicatie strandde toentertijd door financiële problemen, wederzijdse misverstanden en wellicht wrevel bij de uitgever. ${ }^{58}$ Voor deze nieuwe poging werkte Carmona Baez samen met de auteur van dit artikel en David Castle van Pluto Press. Pluto Press is een linkse en activistische uitgever die zich richt op 'de tradities van het marxisme, anarchisme en feminisme. ${ }^{59}$ Aangezien de tekst van Wij slaven duidelijk in deze tradities staat, was Pluto Press zeer bereid om de tekst te publiceren. Ook Erica Pomerans, de weduwe van Arnold en tevens diens proeflezer, sloot zich in 2013 enthousiast bij het team aan.

Het initiatief van Carmona Baez werd in 2013, vlak voor het ter perse gaan van het boek, zonder opgave van redenen door de familie geblokkeerd. ${ }^{60}$ Het leek er echter op dat in 2016 - 70 jaar na het

57 Hans Ramsoedh en Peter Sanches, 'De turbulente biografie van een boek: 75 jaar "Wij Slaven Van Suriname", Parbode: Surinaams Opiniemaandblad 4.43 (2009) 70-72.

58 Boots en Woortman, Anton de Kom, 420-421. Verder ook e-mailcorrespondentie van de auteur met Zed Books, bericht van Dan Och, 11 december 2012. 59 Pluto Press, 'About Us', http://www.plutobooks.com/page/about_us (geraadpleegd februari 2017). 60 E-mail van Antoine de Kom aan Antonio Carmona Baez, 19 september 2013. E-mail is in bezit van de auteur. overlijden van De Kom - de rechten van de erfgenamen zouden verlopen. Bij een tweede poging, drie jaar later, werd duidelijk dat de erfgenamen vooral politieke bezwaren tegen de publicatie hadden. Nadat (door de auteur van dit artikel) de drukproeven waren gecorrigeerd en de index gemaakt, kwam er een brief van de advocaat van Antoine de Kom (kleinzoon van De Kom) met daarbij het contract waarmee Arnold Pomerans in 1985 alle vertalersrechten over had gedragen aan de erfgenamen. De daarop volgende contacten met Antoine de Kom, die optrad namens de erfgenamen, waren veelzeggend. Antoine de Koms hoofdargument voor het blokkeren van de publicatie was het politieke karakter van een publicatie bij Pluto Press. ${ }^{61}$ De uitgever stelde de erfgenamen voor dat de tekst zonder inleiding zou kunnen worden gepubliceerd, als dit de angst voor een te ideologisch geladen context zou wegnemen. Dit voorstel werd echter verworpen door Antoine de Kom, op grond van het feit dat Pluto Press geen 'politiek neutrale' uitgever is. ${ }^{62}$

Hoewel een klein voorbeeld, past het goed bij de lijn van de familie en biografen die benadrukken dat een overvloed aan rode bewegingen zich ten onrechte de erfenis van De Kom hebben toegeëigend. De weerstand van de familie tegen 'politiek' lijkt vooral sentimenteel van aard en kan worden herleid naar de vijandigheid van Nel Borsboom tegen politiek activisme. ${ }^{63}$ De weerstand tegen ideologische toe-eigening van De Kom heeft wellicht meer

61 Dit argument heeft Antoine de Kom op meerdere momenten benadrukt onder andere in een telefoongesprek met de auteur op 5 november 2015 om 21:00. 62 E-mail van Antoine de Kom aan David Castle van Pluto Press, 10 november 2015.

63 Woortman en Boots, Anton de Kom, 350, 383-384, 419 . 
diepte gekregen sinds het Bouterse-regime zich De Kom in de jaren tachtig als nationaal symbool toe-eigende.

De derde groep bij wie de herinnering aan De Kom de deletie van zijn communisme laat zien is een specifieke groep antiracistische activisten. Deze groep richt zich op een 'dekolonisatie van het denken' in Nederland en geeft daarbij dat denken in sommige gevallen een expliciet anticommunistische invulling. In de publicaties van deze activisten over de erfenis van De Kom verdwijnen zijn ideeën over kolonialisme en klasse naar de achtergrond en komt meer nadruk op zijn oproep tot zwart zelfbewustzijn. De ironie hiervan is dat inspirator van deze stroming, Sandew Hira, in de jaren tachtig een prominente rol speelde in de canonisatie van Anton de Kom in zijn boek Van Priary tot en met De Kom (1982). ${ }^{64}$ Hira had in dit boek een maatschappelijk doel en een expliciet marxistisch uitgangspunt. Hij benadrukte hoe De Kom had gepleit voor het overwinnen van etnische tegenstellingen in de Surinaamse samenleving om een gemeenschappelijke strijd tegen het kolonialisme te organiseren. ${ }^{65}$ Dit boek maakte van De Kom een referentiepunt voor Surinaamse denkers en activisten die op zoek waren naar een samenhangend wereldbeeld en historische inspiratie. ${ }^{66}$ Het is illustratief voor de in dit artikel bedoelde deletie dat we bij Hira later een scherpe vorm van uitwissing van De Koms politieke idealen vinden.

Hoewel Hira Anton de Kom vereeuwigde in zijn marxistisch geïnspireerde

64 Sandew Hira, Van Priary tot en met De Kom; De geschiedenis van het verzet in Suriname, 1630-1940 (Rotterdam 1982).

65 Ibidem.

66 Meel, 'Anton de Kom and the formative phase'. geschiedenis van het antikoloniale verzet in Suriname heeft hij sindsdien zijn marxistische kijk op de wereld ingeruild voor een vorm van dekoloniaal denken waarin klasse ondergeschikt is aan koloniale en raciale machtsverhoudingen. Hira heeft voor het bevorderen van dit dekoloniaal denken het International Institute for Scientific Research opgericht, een website voor discussies en publicaties. Op deze site publiceerde Hira in 2012 een research paper onder de titel 'Twee stromingen in de Surinaamse geschiedschrijving' ${ }^{67}$ In dit programmatische artikel opent hij de aanval op wat hij ziet als de witte of koloniale kijk op de geschiedenis. Hij schrijft dit in de vorm van een scherp verwoorde verdediging van Anton de Kom. Opvallend is echter dat hij geen enkele melding maakt van De Koms eigen politieke sympathieen. De Kom is bij Hira uitgegroeid tot een moreel anker voor dekoloniaal denken, maar is daarbij eerst vrijgemaakt van zijn communistisch verleden. De communistische en anti-imperialistische organisatorische context van De Kom wordt niet genoemd. In plaats daarvan kiest Hira voor een make-over van De Kom als activist voor negritude. Hoewel het klopt dat De Kom hierin geïnteresseerd was, is vooral de deletie van het communistische antikolonialisme van De Kom opvallend. ${ }^{68}$

\section{Conclusie}

Het is duidelijk dat zowel de Surinaamse staat, de familie en activisten alle drie hun redenen hebben om te vergeten dat De Kom een communist was. Zij staan hierin

67 Sandew Hira, 'Twee stromingen in de Surinaamse geschiedschrijving', IISR Research Papers nr. 1 (2012). 68 Ibidem. 
niet alleen, ook bij de organisatie van de jaarlijkse Anton de Kom-lezing (georganiseerd door het Verzetsmuseum en dagblad Trouw) lijken de organisatoren zich geen raad te weten met de communistische sympathieën van De Kom. Degenen die de lezing uitspraken hebben, als zij aan De Koms politieke sympathieën refereerden, vaak de behoefte gehad zijn communisme te relativeren of regelrecht te ontkennen. ${ }^{69}$ Communisme strookt immers niet met de boodschap van tolerantie en universele menselijke waardigheid die de organisatoren en sprekers willen uitdragen.

Toch is de deletie van De Koms communisme niet absoluut. Hoewel de kans klein is dat de officiële herinnering aan Anton de Kom in Suriname op dit punt zal veranderen en het ook onwaarschijnlijk lijkt dat de erfgenamen van De Kom het communistisch denken van hun voorvader onder ogen willen komen, lijken er toch nieuwe aanzetten te zijn om de problematische erfenis onder ogen te komen. Zeer recent stuitte een nieuwe generatie activisten bij het aanleggen van The Black Archives in Amsterdam op boeken en documenten die getuigen van de gedeelde zwarte en communistische wortels van de strijd in het Nederlandse imperium. Hun bekende en nog onbekende helden blijken verbonden met anti-imperialistische en communistische bewegingen uit de twintigste eeuw. ${ }^{70} \mathrm{Na}$ aanvankelijk een ontmoetingscentrum te hebben gevormd rond de boekenverzameling van Waldo

69 De teksten van de redevoeringen staan op de website van het Verzetsmuseum www.verzetsmuseum.org. De verwijzingen naar de lezingen zijn het eenvoudigst te raadplegen via https://nl.wikipedia.org/wiki/ Anton_de_Kom-lezing (geraadpleegd mei 2017). 70 The Black Archives, http://www.theblackarchives.nl/ (geraadpleegd maart 2017).
Heilbron in Amsterdam Noord moesten activisten van de New Urban Collective (NUC) op zoek naar een nieuwe plek om deze collectie te huisvesten.

Ze vonden die in de Vereniging Ons Suriname (VOS). Deze vereniging heeft een lange geschiedenis in Nederland gehad en had als prominent lid Otto Huiswoud, de uit Suriname afkomstige medeoprichter van de Amerikaanse communistische partij. De NUC maakte met de VOS de afspraak dat NUC de boekencollectie kunnen huisvesten als NUC het Huiswoud archief op orde maken. Huiswoud publiceerde als redacteur van The Negro Worker De Koms Engelstalige artikel. Door het oog van het Huiswoud-archief en het organiseren van de Heilbron collectie komt de rode draad aan het licht die veel van de zwarte bewegingen internationaal verbond. De 'roodheid' van de zwarte activisten duikt op, maar nu buiten de context van de Koude Oorlog. Wat door de herontdekking van Huiswoud in gang wordt gezet zal ongetwijfeld ook de herinnering aan De Kom in de toekomst gaan vormen. ${ }^{71}$

\section{Over de auteur}

Dr. Karwan Fatah-Black is universitair docent aan het Instituut voor Geschiedenis in Leiden. Hij onderzoekt de vroegmoderne geschiedenis van het Nederlandse wereldrijk. In 2016 ontving hij van de KNAW de Heineken Young Scientist Award voor zijn onderzoek naar de Surinaamse geschiedenis.

E-mail: k.j.fatah@hum.leidenuniv.nl

71 'Vergeten verhalen op de Biënnale van Venetie door Cinema Olanda', http://www.theblackarchives.nl/blog/category/otto-huiswoud (geraadpleegd maart 2017). 
